\title{
THE FEDERAL INCOME TAX AND REGULATED TRANSPORTATION
}

\author{
James G. Gidding* and Arnold B. McKinnon†
}

If the ability to pay taxes, particularly those based on income, is a criterion of the efficiency of a mode of transportation, the clear superiority of the railroads is amply demonstrated. Their income taxes alone in 1957 exceeded the total taxes paid by the transportation industry's next largest taxpayer, the regulated motor carriers. (See table.) Unfortunately, however, these enormous taxes are not an index of

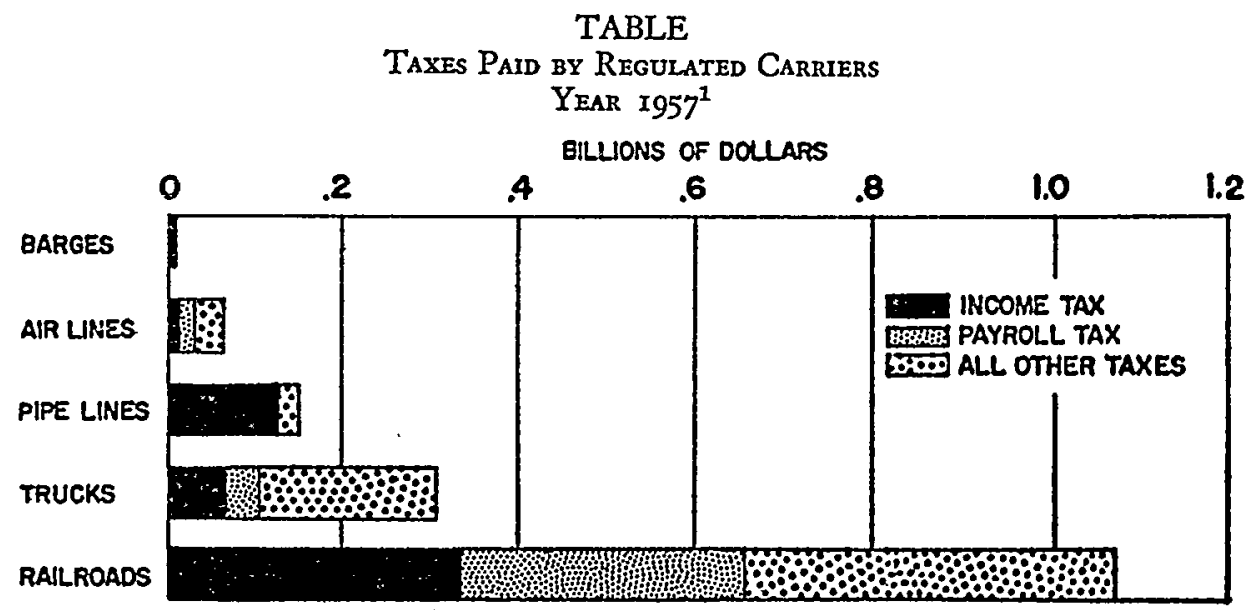

railroad prosperity. Thus, net railway operating income in 1957, of about $\$ 922,000,000$, constituted a return of only $3.3^{6}$ per cent upon the railroads' average net property investment. ${ }^{2}$ For the year, their net income (reflecting the inclusion of other than railway operating income and the deduction of interest) was only $\$ 737,000,000$, or 2.66 per cent return on this investment. ${ }^{3}$

It is not surprising, therefore, that by the end of 1957 , the financial situation of the railroad industry was extremely serious. The Senate Committee on Interstate and Foreign Commerce observed: ${ }^{4}$

"B.S. 1943, Georgetown University; M.A. 1948, Ohio State University; LL.B. 1950, University of Virginia. Member of the Virginia and Ohio bars; General Tax Attorney, Southern Railway System.

+A.B. 1950, LL.B. I95x, Duke University. Member of the North Carolina and District of Columbia bars; Assistant General Tax Attorney, Southern Railway System.

${ }^{1}$ ICC, Bureau of Transport Economics and Statistics, Seventy-girst AnN. Rep. on Tiunsport Statistics in the United States for the Yeik ENDed Dec. 31, 1957, at 1, 6, 9-1 1, 22-23, 116,130 (1958); CAB Form 4I, Schedule P-4I, for the year ending Dec. 31, 1957 .

'See Ass's of Soctheastern Railroads, Railroad Information 22, 50, 70 (1959). As a comparison, the United States Treasury recently sold one-year bills ". . . at a price equivalent to an average yield of $4.728 \%$." Wall Street Journal, July 9, 1959, p. 3, col. 3 .

${ }^{3}$ Ass'N of Southeastern Ratlmoads, op. cit. supra note 2 , at 50.

Senate Comm. on Interstate and Foreign Commerce, Transportation Act of 1958, S. Rep. No. 1647, 85th Cong., 2d Sess. 7 (1958). 
Because of the essential part the railroads play in our whole transportation system it was a cause of great concern to your subcommittee when we observed the rapid deterioration of the railroad position in the fall of 1957.

It was clear . . . that not only were the railroads being adversely affected by the business recession which was then appearing, but that, in fact, the sickness of the railroads was contributing greatly to the deepening recession of the Nation.

In 1958 , net railway operating income continued to decline to $\$ 762,000,000$, or a rate of return of 2.76 per cent. Net income was less than $\$ 602,000,000$, or a return of less than 2.2 per cent on the net property investment of $1958 .^{5}$ For the first five months of $r 959$, net income “. . . totaled $\$ 247$ million, up from $\$ 75$ million in the like part of 1958 but down from $\$ 289$ million in the January-May period of $1957 . " 6$

At the end of June 1959, the Senate Committee stated: ${ }^{7}$

Freight car shortages, of varying duration and severity, have plagued this country and its shippers for more than a generation....

The railroads, the Interstate Commerce Commission, and other transportation experts, have wrestled with this perennial problem for many years, but it still persists and, in many respects, has become progressively worse. It is now a problem of major national importance, not only from the viewpoint of the railroads and their employees, but also from the viewpoint of the Nation's shippers and, indeed, from the viewpoint of the national defense. This stark fact is universally recognized, unchallenged, and supported by the testimony offered before this committee.

The depressed condition of the industry is not simply or easily explained by pointing to one or two factors. ${ }^{8}$ Certainly, increased competition, deliberately sponsored in large part by the federal government, is most important. Such competition, in many ways uneconomic, has depressed the revenues of the rail-

-Ass'N of Southeastern Railroads, op. cit. supra note 2, at 22, 50.

${ }^{-}$Wall Street Journal, July 7, 1959, p. 23, col. 2. Because of the steel strike, “. . . net railway operating income for the 12 months of 1959 may not top $\$ 800$ million-although pre-strike estimates put the probable figure at $\$ 950$ million." Railway Age, Oct. 5, I959, p. 9 .

'Senate Comm. on Interstate and Foreign Commerce, Freight Car Supply, S. REP. No. 452, 86th Cong., Ist Sess. 2 (1959).

${ }^{8}$ The Senate Committee found that the railroads suffered from ". . . the development of newer methods of transportation that offer intense competition to the railroads [including] the development of airplanes, and the building of modern highways on which move a large number of buses and trucks . . . ; the Govcrnment assistance offered to the railroads' competitors [including] the building of highways and airports, the provision of toll-free waterways, and other facilities . . overregulation . . . usually under laws and procedures that are ancient and outmoded," and finally "a failure to compete aggressively for business by use of modernized equipment, by adjustments in plant and financial structures, as well as failure to adjust rates to compete effectively for traffic." Senate Comm. on Interstate and Foreign Commerce, Transportation Act of 1958 , S. REP. No. 1647,85 th Cong., 2d Sess. Io (1958). Another problem remains the $10 \%$ tax imposed upon travel. The tax was imposed to discourage passenger traffic, principally rail, during World War II. It continues this function most effectively. In examining the railroad passenger train deficit, an ICC Examiner recently commented upon a government economist's recommendation that rail fares should be reduced, stating: ". . . the Government, for which this witness spoke, could do much toward increasing the attractiveness of railroad travel simply by agreeing to the rcmoval of the ro-percent Federal tax on such travel. Unless and until they are willing to take this step, any assertion on their behalf that railroad fares exceed a proper level based on value of services is not likely to be taken seriously." Railroad Passenger Train Deficit, No. 31954, Examiner's Proposed Report, ICC, Sept. r8, 1958 . 
roads. Even so, the situation of the railroads would not be so serious were it not for the fact that these reduced earnings are further depleted by high taxes, including the federal income tax, and for the fact that the amount of the railroads' income subjected to tax is increased by outmoded depreciation concepts. As the Senate Committee investigating the freight car shortage stated $:^{0}$

Inadequate earnings by some of the railroads are an important factor. The high cost of new freight cars, coupled with unrealistic depreciation allowances, is doubtless a contributing factor.

Certainly a large part of the railroads' financial problem is caused by the combined effect of high income tax rates and low income tax depreciation allowances. These barriers to investment must be reduced if the industry is to provide the equipment demanded by the Congress and to make increasing use of technological advances now available, as demanded by the national interest.

\section{The Tax Rate}

On June 30, 1959, the President signed H.R. 7523, "an act to provide a one-year extension of the existing corporate normal tax rate. ..."10 This act continues the Korean War provision under which the federal government taxes the income of corporations at the rate of fifty-two per cent. The fifty-two per cent rate was established in the Revenue Act of I95I, and was originally limited to expire April I, I954..$^{11}$ In approving the increase of five per cent in the corporate normal tax rate which took place at that time, the Senate Finance Committee stated: $\mathbf{1 2}^{\mathbf{2}}$

The rate increase provided by your committee's bill is much larger than it would ordinarily be desirable to provide, and it is realized that if corporate rates are continued at this high level indefinitely the expansion of productive facilities may be seriously impaired.

Certainly, the fifty-two-per-cent rate has had this effect on the railroads. As one railroad president expressed it, "The railroads are half-soling their shoes beyond reason." 13 Or, in the language of economics: ${ }^{14}$

The main effect of such a high corporate investment threshold is to hold an umbrella over existing productive facilities. For it defers the introduction of new capacity competitive therewith. Old facilities must become more decrepit and inefficient before they are

\footnotetext{
'Senate Comm. on Interstate and Foreign Commerce, Freight Car Supply, S. REp. No. 452, 86th Cong., Ist Sess. 3 (1959).

${ }^{10}$ Tax Rate Extension Act of 1959, 73 Stat. 157.

11 Revenue Act of 195I, $\$$ I2I, INT. REv. CODE of 1939, \$ I3.

${ }^{12}$ Senate Comm. on Finance, The Revenue Act of 195I, S. REP. No. 781, 82d Cong., 1st Sess. $\mathrm{r}_{4}$ (195I).

${ }_{18}$ Hearings Before the Subcommittee on Surface Transportation of the Senate Committee on Interstate and Foreign Commerce on Problems of the Railroads, 85th Cong., 2d Sess. pt. 1, at 139 (1958).

${ }^{14}$ George W. Terborgh, Effect of the Corporate Income Tax on Investurent it (i959).
} 
replaceable. Their service lives are extended. The economy drags along in consequence with a productive mechanism of greater average age, and with more accumulated deterioration and obsolescence, than would obtain in the absence of the tax.

Furthermore, the deterrent effect of the high income tax on the introduction of new and modern capacity is not uniform. To the extent that the company or industry involved can shift the incidence of the tax to its market, the effect is less pronounced than where the corporation must absorb the tax. It has been felt, for example, that a regulated public utility shifts practically all the tax burden, as the tax becomes an item of expense entering into its rate structure. ${ }^{15}$ This, of course, is intimately connected to the proposition that a regulated rate must provide a fair return upon the investment. ${ }^{16}$ The extreme effect upon the railroad industry is obvious, therefore, since it is both regulated and highly competitive with other forms of transportation, so that its rate of return has been extremely small.

"The deterrent effect of the tax on investment is relatively greater for nondepreciable assets such as land, inventory, and the like, than for wasting assets such as buildings and equipment."17 Here, again, the railroad industry is penalized by the high tax rate, for a vast amount of its investment is in such important nondepreciable items as land and grading constituting its roadbed. ${ }^{18}$ As the roadways of competing carriers are generally furnished at taxpayers' expense, the penalty of the high tax is multiplied once more.

\footnotetext{
I5 "If the shifting is less than complete in some cases, it is because the utility is subject to competition and cannot benefit from fully tax-inclusive rates." Id. at 9 .

${ }^{10}$ If the present high tax rate is to be retained much longer, recognition should be given to the principle expressed in the Excess Profits Tax Act of 1950, INT. Rev. Cone of 1939, $\$ 44^{8}$, establishing a special excess profits credit for regulated public utilities. The effect and purpose of this minimum credit was stated to be ". . . to give assurance that an excess profits tax will not be imposed on the specified regulated industries until after they earn a rate of return of 6 percent or 7 percent after paying corporate normal taxes and surtaxes (including the 2 percent additional tax for consolidated returns). Your committee believes that this is appropriate in view of the fact that the profits of these industries in the base period years were held down well below the profits earned by unregulated industries. Moreover, there is considerable evidence that rate adjustments for these industries lagged considerably behind increases in their costs of doing business. Your committee also believes that where industries are regulated by governmental bodies providing only a fair rate of return it is undesirable to consider profits allowed by such regulatory bodies as excessive for purposes of an excess profits tax, especially where the corporations are held to a relatively low rate of return. However, it should be clear that in establishing the rates of return provided by this minimum credit your committee is not in any way attempting to set a rate of return which would be proper for regulative purposes but only is concerned with the problem of establishing uniformity for purposes of determining income which should be subjected to excess profits tax." Senate Comm. on Finance, Excess Profits Tax Act of 1950, S. Rep. No. 2679, 81st Cong., 2d Sess. 31 (1950).

17 TERBorgk, op. cit. supra note $\mathrm{I4}$, at 13 .

${ }^{18}$ In addition, much rail property is operated under leases (usually entered into before 1940, many before 1900) which provided that the leased property shall be returned in good condition at the end of the lease term, perhaps 99 or 999 years later. The Internal Revenue Service refused to allow either lessor or lessee any depreciation on such leased property (whether buildings, old steam facilities, or handpowered velocipedes), and heretofore has been upheld by the courts in many cases. See, e.g., Atlantic Coast Line R.R. v. Commission, 8I F.2d 309 (4th Cir. 1936). The unreasonableness of the Internal Revenue Service approach, which ignores obsolescence entirely, is now judicially recognized. See North Carolina Midland Ry. v. United States, I63 F. Supp. 610 (Ct. Cl. 1958).
} 


\section{Deprectation}

As the high corporate tax rate bears more heavily upon the railroad industry than upon its competitors, or industry in general, the importance of depreciation as a source of funds to provide needed capacity and modernization cannot be overstated. Once again, however, the industry is placed at an enormous disadvantage.

It is a matter of common knowledge that railroad depreciable property is extraordinarily long lived-lives of 50 to 100 years have been used generally in respect of roadway structures and lives up to 35 years on equipment. The average overall rate for the industry is but little more than 2 percent. It is obvious that this meager flow of free cash is absolutely inadequate to meet even the downpayment for replacements in these days of inflated cost. It is equally clear that in the light of present technological advancement and high costs, no taxpayer should be required to wait such inordinate lengths of time to recover his capital investment in depreciable property.

The position of the railroad industry with its small depreciation deduction based on its long lived assets compares most unfavorably with its competitors with respect to whose depreciable assets relatively short lives have been accorded; aircraft, for example, 5 years; heavy trucks and buses for long distance use, 8 and 7 years, respectively. The mere statement of this comparison completely expounds the competitive difficulty in this aren. In such an era of change, both in the way of doing things and in the diminishing value of the dollar, it is transparently clear that modernization and efficiency can more easily be accomplished by our competitors who recover their capital cost over a short period of time than is the case with the railroads which realize the need for such activity in order to continue to exist, but which are hampered in so doing in large measure by so little annual cash recovery due to their long-lived property. ${ }^{19}$

\section{III}

\section{Two Proposals}

The railroads have two proposals to correct this discriminatory tax burden now placed upon them by the federal income tax. One proposal would merely tend to correct the long lives heretofore assigned to railroad property, as compared to those allowed its competitors. The present disparity of perhaps four-to-one would be reduced to something like two-to-one. The second, which would be available to other carriers as well, would stimulate necessary and continuing investment in needed transportation facilities.

\section{A. Maximum Life}

The first proposal would give great, long-overdue, relief from the unrealistic depreciation rates given railroad equipment and other depreciable property. It would, in effect, recognize that obsolescence, rather than mere physical wear and tear, has

\footnotetext{
${ }^{19}$ Fearings, supra note $\mathrm{I}_{3}$, at 32-33. The Senate Committee concluded as a result of this and other testimony: "As it is now, extremely long service lives ranging in some cases from 50 to I00 ycars, are assigned to depreciable railway property of the railroads. These long lives attributed to railroad property for tax purposes are wholly unrealistic and constitute a severe handicap." Senate Comm. on Interstatc and Foreign Commerce, Transportation Act of 1958, S. REP. No. 1647, 85th Cong. 2d Sess. 7 (1958).
} 
come to the forefront as the factor determining the economic usefulness of rail equipment, quite as much as that of the equipment employed by other regulated carriers. Rolling stock would be given a maximum tax life of fifteen years; and other depreciable property, such as repair shops, a maximum life for tax purposes of twenty years. ${ }^{20}$ Adoption of this simple proposal would be a long step forward in correcting the obsolescence now current in the railroad plant. As pointed out above, high taxes and long depreciation lives produce a high investment "threshold" and lead to continuing in service equipment which has passed its true economic usefulness, though it may be patched into continued service.

\section{B. Construction Reserve}

The second proposal would permit the carrier to establish a "construction reserve fund" patterned upon similar reserves first established for the Merchant Marine in 1936..$^{21}$ Under this proposal, a carrier might establish a construction reserve fund into which deposits would be made and deducted from income annually, up to an amount equal to the carrier's book depreciation for the year. ${ }^{22}$ To the extent that equipment or other transportation facilities are paid for from the fund, they would have no tax depreciation basis. Thus, the tax on the amounts deposited would not be forgiven, but would be merely deferred over the life of the property purchased. If the funds are not used for approved purposes within five years or are diverted to other purposes, such as the payment of dividends, they would be subject to tax at the rate at which they were deducted, plus interest during the interim.

Neither of these proposals would have the effect of tax forgiveness; both would defer taxes to the future. That such tax deferral can produce needed investment was amply demonstrated by the amortization programs of World War II and the Korean War. As was recognized in each case, amortization merely postponed the tax and did not forgive it. A study prepared by the staff of the Joint Committee on Internal Revenue Taxation found $:^{23}$

The experience through 1953 indicates that a rapid amortization program can stimulate railroad expansion to the point of being able to handle the demand during the annual peak

${ }^{20}$ See, e.g., H.R. 7212, 86th Cong., Ist Sess. (1959).

${ }^{31}$ Merchant Marine Act of $1936, \S 607(\mathrm{~h}), 49$ Stat. 2005,46 U.S.C. $\$$ II77 (1952); $\$ 510(e), 53$ Stat. Ir83 (1939), 46 U.S.C. $\$$ I 160 (1952); 5 II, 54 Stat. Iro6 (1940), 46 U.S.C. \$ II6I (1952).

22 "Recognizing the importance of maintaining the railroad industry, and other common carriers, in a state of operational efficiency and being assured that the transportation industry is unable by reason of its financial condition adequately to maintain, replace, or modernize its facilities and plant, the subcommittce has determined that this proposal is reasonable and appropriate. Taxes are deferred pursuant to this proposal; not forgiven. It is believed that aside from the immediate beneficial effect that will result from this proposal, it will also have a long-range beneficial effect, not only on the operating efficiency of the carriers, but also on our economy. The use of this fund as a means of providing for capital replacement or expansion would also seem to provide a means whereby the level of procurement in this industry would be constant despite the rise and fall in the economy. This, of course, contributes to an orderly and stable economy redounding to the benefit of all." Senate Comm. on Interstate and Foreign Commerce, Transportation Act of 1958, S. REP. No. 1647,85 th Cong., 2 d Sess. 17 (1958).

${ }^{23}$ Staff of Joint Committee on Internal. Revenue Taxation, 84th Cong., 2 D Sess., Report on 5-Year Amortization of Emergency Defense facilities Under Section I68 of the INternal RevENUE CODE OF 1954, at 35 (Comm. Print. 1956). 
periods. This was accomplished in 1953 at the expense of having a surplus of available cars equal to 2 to 5 per cent through 8 of the 12 months. The previous analysis suggested that operating by themselves the railroads probably would not accommodate this demand without car shortages during the harvest season. The fact that the railroads were able to handle this peak demand without shortages during 1953 is significant as a result of the emergency amortization program.

As this experience demonstrates, needed equipment and other transportation facilities can be financed and such investment can be stimulated by shortening the depreciation period for existing rail facilities and by adopting a "construction reserve" available to all carriers. 